\title{
Sistem Informasi Penyaluran Donasi Berbasis Web
}

\author{
Fabriyan Fandi Dwi Imaniawan \\ Program Studi Sistem Informasi, STMIK Nusa Mandiri \\ fabriyan.fbf@nusamandiri.ac.id
}

\begin{abstract}
The implementation of information system is absolutely important for an institution or social organization in the millennial era. Media is needed to fulfill perceived social needs for information and services, such as a website. For an institution or social organization, the website currently has an important role. In terms of online donations distribution, website is required for conveying information and creating donation services to the donor through internet access or by online. The manual acceptance and distribution donations are the existing problems in transaction management. Therefore transparency on the donation report is still limited and requires a long time process. This causes a slow process of making reports because of the many unconfirmed donations. In this research, a web-based donation distribution system is created using the waterfall method, starting from software analysis, design, program code creation, testing to maintenance. The system is expected to manage processss from receiving transactions to distributing donations effectively and efficiently, resulting to a transparent financial report for donors.
\end{abstract}

\section{Keywords: Donation, Social Organization, Website}

Abstrak: Penerapan sistem informasi pada era millenial saat ini sangat penting dilakukan bagi sebuah lembaga ataupun organisasi sosial. Diperlukan adanya media untuk memenuhi kebutuhan akan informasi dan layanan, seperti website. Bagi sebuah lembaga maupun organisasi sosial, website saat ini memiliki peran yang penting. Misalnya, dalam hal penyaluran donasi perlu adanya media website untuk membantu dalam menyebarkan informasi dan membuka layanan donasi untuk para donatur melalui internet atau secara online. Permasalahan yang muncul selama ini terdapat di dalam pengelolaan transaksi donasi yang masih manual sehingga membutuhkan waktu yang lama. Hal ini menyebabkan lambatnya proses pembuatan laporan karena banyaknya donasi yang belum terkonfirmasi. Dalam penelitian ini, dibuatlah sistem penyaluran donasi berbasis web menggunakan metode waterfall, mulai dari analisa perangkat lunak, desain, pembuatan kode program, pengujian dan pemeliharaan. Diharapkan dengan adanya sistem ini, pengelolaan dari transaksi penerimaan hingga penyaluran donasi dapat lebih efektif dan efisien sehingga berpengaruh kepada pembuatan laporan keuangan yang dapat dipertanggungjawabkan secara transparan kepada donatur.

Kata kunci: Donasi, Organisasi Sosial, Website

\section{A. PENDAHULUAN}

Di era sekarang, sistem informasi semakin berkembang seiring dengan meningkatnya kebutuhan akan ketersediaaan informasi yang tepat, akurat, terpercaya serta tersusun rapi dan terintegrasi dengan baik. Dengan demikian, penerapan sistem informasi merupakan hal yang sangat penting untuk dilakukan. Guna memenuhi kebutuhan akan informasi dan layanan, diperlukan adanya media yang diciptakan untuk menyajikan informasi dan layanan seperti website.

Menurut (Misriati, 2015), "Sistem Informasi adalah Suatu sistem yang mempertemukan kegiatan strategi dan kebutuhan transaksi suatu organisasi yang menyediakan laporan-laporan ke pihak luar tertentu dengan yang diperlukan". Sistem informasi berbasis web sangat 
dibutuhkan oleh lembaga maupun organisasi sosial untuk membantu dalam menyebarkan informasi dan membuka layanan seperti donasi untuk para donatur melalui internet. Donasi yang diberikan dapat berupa uang, barang, pakaian, makanan, bantuan kemananusiaan saat terjadi bencana alam atau bantuan dalam bentuk pembangunan, perawatan medis berupa pemberian transfusi darah dan transplantasi berupa pemberian penggantian organ dalam (Nurromlah, Yuri Rahayu, 2017). Dengan adanya website maka informasi akan lebih cepat menyebar dan pelayanan donasi akan lebih efisien.

Sistem penyaluran donasi saat ini masih banyak yang menggunakan cara-cara manual misalnya saja para donatur harus datang ke posko untuk donasi, pencatatan data transaksi masih menggunakan kuitansi manual, dan yang terbaru donasi melalui transfer bank tanpa adanya konfirmasi ke organisasi atau lembaga tersebut. Hal ini menyebabkan lambatnya proses pembuatan laporan karena banyaknya donasi yang belum terkonfirmasi serta laporan pemasukan dan pengeluaran dana kepada donatur yang tidak transparan. Sebagai lembaga ataupun organisasi yang bergerak di bidang sosial, perlu adanya sikap keterbukaan dan memberikan fasilitas yang memudahkan donatur untuk berdonasi. Dengan kemajuan teknologi saat ini, beberapa lembaga ataupun organisasi sosial juga kurang memanfaatkan kemajuan tersebut dengan bukti hanya adanya akun sosial media Facebook milik anggota organisasi sebagai tempat penyebaran informasi sehingga banyak masyarakat yang belum mengetahu.. Maka diperlukan adanya suatu alternatif atau solusi untuk bisa mempercepat kinerja pengelola dalam upaya membangun kepercayaan yaitu dengan membuat sebuah website yang transparan kepada donatur. Dengan adanya website, penyebaran informasi akan lebih tertata, pengelolaan data donasi yang masuk dalam laporan keuangan dapat lebih mudah serta transparansi laporan keuangan kepada donatur akan meningkatkan kepercayaan donatur yang ingin melakukan donasi.

\section{B. TINJAUAN PUSTAKA}

\section{Sistem Informasi}

Sistem Informasi menurut (Firman et al., 2016), "Kombinasi teratur dari orang-orang, perangkat keras atau hardware, perangkat lunak atau software, jaringan komunikasi, dan sumber daya data yang mengumpulkan, mengubah, dan menyebarkan informasi dalam sebuah organisasi"

\section{Teknologi Website}

a. Website

Menurut (Ahmad \& Hermawan, 2014), "Website merupakan kumpulan halaman yang menampilkan informasi data teks, data gambar diam atau gerak, data animasi, suara, video, atau gabungan dari semuanya, baik yang bersifat statis maupun dinamis yang dimana masing-masing dihubungkan dengan jaringan-jaringan halaman (hyperlink)."

b. HTML

Hypertext Markup Language atau HTML adalah bahasa yang digunakan pada dokumen web (Prasetyo, 2015). Dengan kata lain, HTML merupakan bahasa pemrograman berupa tagtag yang digunakan untuk membuat dan mengatur penampilan dari halaman website.

c. PHP

Menurut Nugroho dalam (Imaniawan \& Elsa, 2017), "PHP adalah bahasa standar yang digunakan dalam website. PHP adalah bahasa program yang berbentuk skrip yang diletakan di dalam server web".

d. Cascading Style Sheet (CSS)

Menurut Sibero dalam (Imaniawan \& Elsa, 2017), "CSS memiliki arti gaya menata halaman bertingkat, yang berarti setiap satu elemen yang telahdiformat dan memiliki anak yang telah diformat, maka anak dari elemen tersebut secara otomatis mengikuti format elemen induknya".

e. Menurut Wahana Komputer dalam (Imaniawan \& Elsa, 2017), “JavaScript merupakan skrip yang paling banyak digunakan dalam pemrograman web pada sisi client. Dengan JavaScript sebuah web akan lebih hidup, cepat, dan tampil lebih menawan dengan animasi".

f. $M y S Q L$

Menurut Nugroho dalam (Mulyanto \& Khasanah, 2018), "MySQL (My Structured Query Language) atau yang biasa dibaca mal-se-kuel adalah sebuah program pembuat dan 
pengelola database atau yang sering disebut dengan DBMS (Database Management System), sifat dari DBMS ini adalah open source".

\section{ERD}

Menurut (Yanto, 2016) "ERD adalah suatu diagram untuk menggambarkan desain konseptual dari model konseptual atau basis data relasional". ERD terdiri dari 3 komponen utama yaitu Entitas (entity), Atribut (attribute), dan Relasi (relationship)

\section{LRS}

Menurut (Tabrani, 2014) "Logical Record Structure dibentuk dengan nomor dari tipe record". Beberapa tipe record digambarkan oleh kotak persegi panjang dan dengan nama yang unik. Perbedaan LRS dan E-R diagram adalah tipe record ditempatkan. Logical Record Structure terdiri dari link-link diantara tipe record.

\section{BlackBox Testing}

Menurut (Rosa \& Salahudin, 2013) "Black-Box Testing yaitu menguji perangkat lunak dari segi spesifikasi fungsional tanpa menguji desain dan kode program". Blackbox testing digunakan untuk mengetahui apakah fungsi-fungsi, masukan, dan keluaran sesuai dengan spesifikasi yang dibutuhkan.

\section{Struktur Navigasi}

Menurut (Andriansyah, 2016), "Struktur navigasi dapat diartikan sebagai alur dari suatu program yang menggambarkan hubungan antar area yang berbeda sehingga memudahkan proses pengorganisasian seluruh elemen website". Terdapat 4 jenis struktur navigasi, diantaranya Stuktur Navigasi Berurut (Linear), Struktur Navigasi Tidak Berurut (Non-Linear), Stuktur Navigasi Hirarki, dan Stuktur Navigasi Campuran

\section{METODE PENELITIAN}

Metode yang digunakan dalam penelitian ini adalah dengan metode waterfall menurut Rosa dan Shalahudin dalam (Supriyanta \& Nussy, 2016) yang dibagi menjadi lima tahapan, yaitu:

\section{Analisis kebutuhan perangkat lunak}

Proses pengumpulan kebutuhan dilakukan secara intensif untuk menspesifikasikan kebutuhan perangkat lunak agar dapat dipahami perangkat lunak seperti apa yang dibutuhkan oleh user. Spesifikasi kebutuhan perangkat lunak pada tahap ini perlu untuk didokumentasikan supaya proses identifikasi mudah dipahami.

\section{Desain}

Proses multi langkah yang fokus pada desain pembuatan program perangkat lunak termasuk struktur data, arsitektur perangkat lunak, representasi antarmuka, dan prosedur pengodean. Tahap ini mentranslasi kebutuhan perangkat lunak dari tahap analisis kebutuhan ke representasi desain agar dapat diimplementasikan menjadi program pada tahap selanjutnya. Desain perangkat lunak yang dihasilkan pada tahap ini juga perlu didokumentasikan. Desain database menggunakan Logical Record Structure (LRS) dan Entity Relationship Diagram (ERD).

3. Pembuatan Kode Program

Pada tahap ini merupakan pembuatan kode program yaitu desain harus ditranslasikan ke dalam program perangkat lunak menggunakan bahasa pemrograman yang bisa dikenal oleh komputer. Aplikasi yang digunakan yaitu Microsoft Visual Basic 6.0 dan menggunakan database MySQL.

\section{Pengujian}

Pada tahap ini berfokus pada perangkat lunak secara logik dan fungsional dan memastikan bahwa semua bagian sudah diuji. Hal ini dilakukan untuk meminimalisir kesalahan(error) dan memastikan keluaran yang dihasilkan sesuai dengan yang diinginkan. Pengujian ini menggunakan Black box Testing.

5. Pendukung (support) atau pemeliharaan (maintenance)

Perangkat lunak mengalami perubahan ketika sudah dibuat dan dikirimkan ke user, yang terjadi karena adanya kesalahan-kesalahan yang tidak terdeteksi sewaktu perangkat lunak beradaptasi dengan lingkungan baru. 
D. HASIL DAN PEMBAHASAN

1. Analisis Kebutuhan Pengguna

a. Pengunjung

1) Pengunjung dapat melihat panduan donasi

2) Pengunjung dapat mengirim pesan kepada pihak lembaga atau organisasi sosial di buku tamu website

3) Pengunjung dapat melakukan pendaftaran sebagai donatur

4) Pengunjung dapat melihat kegiatan yang dilakukan lembaga atau organisasi sosial.

b. Donatur

1) Donatur dapat melihat aktivitas/kegiatan lembaga atau organisasi sosial

2) Donatur dapat melakukan login ke halaman donatur

3) Donatur dapat melakukan donasi dan konfirmasi

4) Donatur dapat melihat riwayat donasi

5) Donatur dapat melihat laporan donasi.

c. Admin

1) Admin dapat melakukan login ke halaman admin.

2) Admin dapat mengelola data admin

3) Admin dapat mengelola data aktivitas atau kegiatan lembaga atau organisasi sosial

4) Admin dapat mengelola data bank

5) Admin dapat mengelola data donatur

6) Admin dapat mengelola data donasi

7) Admin dapat mengelola data konfirmasi donasi

8) Admin dapat mengelola dan melihat laporan donasi.

\section{Entity Relationship Diagram (ERD)}

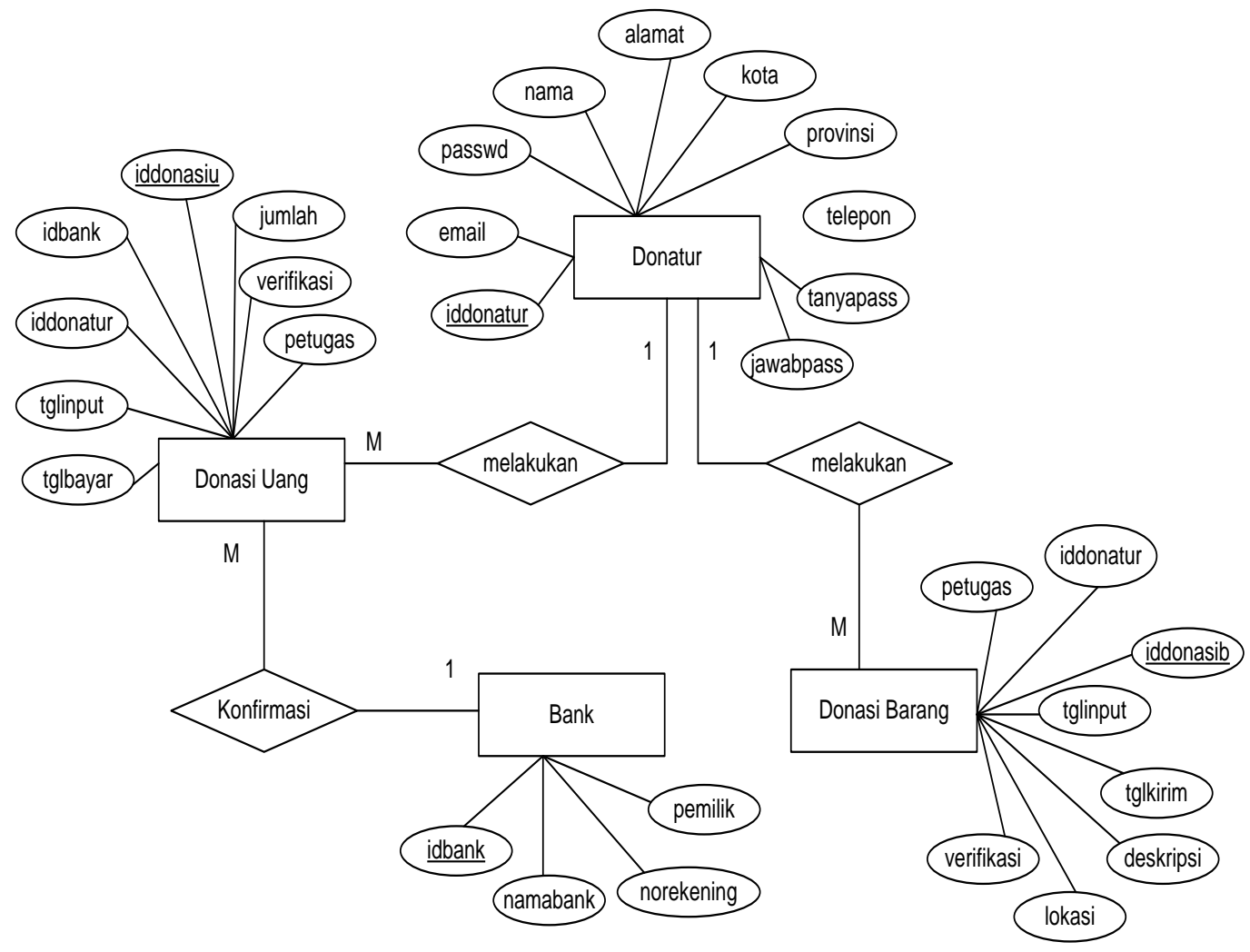

Gambar 1. Entity Relationship Diagram 


\section{Logical Record Structure (LRS)}

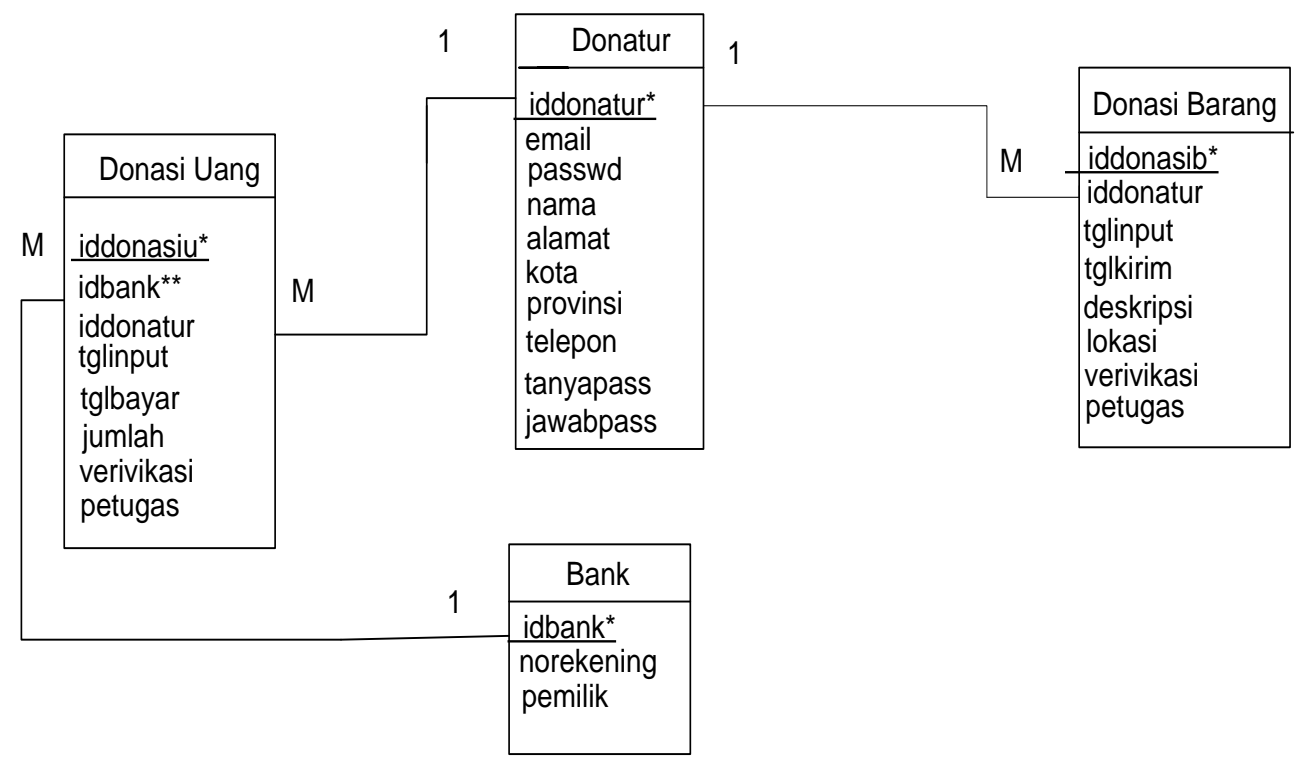

Gambar 2. Logical Record Structure

\section{Rancangan Database}

Tabel 1. Tabel Donasi Barang

\begin{tabular}{|c|c|c|c|c|c|}
\hline No & Elemen Data & Akronim & Tipe & Panjang & Keterangan \\
\hline 1 & Id Donasi & Iddonasib & Int & 10 & Primary Key, Auto Increment \\
\hline 2 & Id Donatur & Iddonatur & Int & 10 & \\
\hline 3 & Tanggal Input & Tglinput & Date & & \\
\hline 4 & Tanggal Kirim & Tglkirim & Date & & \\
\hline 5 & Deskripsi & Deskripsi & Text & & \\
\hline 6 & Lokasi & Lokasi & Text & & \\
\hline 7 & verivikasi & Verivikasi & Date & & \\
\hline 8 & petugas & Petugas & Varchar & 30 & \\
\hline
\end{tabular}

Tabel 2. Tabel Donasi Uang

\begin{tabular}{|c|c|c|c|c|c|}
\hline No & Elemen Data & Akronim & Tipe & Panjang & Keterangan \\
\hline 1 & Id Donasi & Iddonasiu & Int & 10 & Primary Key, Auto Increment \\
\hline 2 & Id Bank & idbank & Int & 10 & \\
\hline 3 & Id Donatur & iddonatur & Int & 10 & \\
\hline 4 & Tanggal Input & Tglinput & Date & & \\
\hline 5 & Tanggal Bayar & Tglbayar & Date & & \\
\hline 6 & Jumlah & Jumlah & Int & 10 & \\
\hline 7 & verivikasi & Date & Date & & \\
\hline 8 & petugas & Petugas & Varchar & 30 & \\
\hline
\end{tabular}

Tabel 3. Tabel Donatur

\begin{tabular}{|c|c|c|c|c|c|}
\hline No & Elemen Data & Akronim & Tipe & Panjang & Keterangan \\
\hline 1 & Id Donatur & Iddonatur & Int & 10 & Primary Key, Auto Increment \\
\hline 2 & NIK & Nik & Int & 12 & \\
\hline 3 & Email & Email & Varchar & 40 & \\
\hline 4 & Password & Passwd & Varchar & 10 & \\
\hline 5 & Nama & Nama & Varchar & 40 & \\
\hline 6 & Alamat & Alamat & Varchar & 100 & \\
\hline 7 & Kota & Kota & Varchar & 30 & \\
\hline 8 & Provinsi & Provinsi & Varchar & 30 & \\
\hline 9 & Telepon & Telepon & Int & 20 & \\
\hline 10 & Tanya Password & tanya pass & Varchar & 50 & \\
\hline 11 & Jawab password & Jawabpass & Varchar & 20 & \\
\hline
\end{tabular}


IJSE - Indonesian Journal on Software Engineering, Vol.6, No. 1, Juni 2020, 44-55 pISSN: 2461-0690 I elSSN: 2714-9935

Tabel 4. Tabel Bank

\begin{tabular}{|c|c|c|c|c|c|}
\hline No & Elemen Data & Akronim & Tipe & Panjang & Keterangan \\
\hline 1 & Id Bank & Idbank & Int & 10 & Primary Key, Auto Increment \\
\hline 2 & Nama Bank & Namabank & Varchar & 15 & \\
\hline 3 & No Rekening & Norekening & Varchar & 20 & \\
\hline 4 & Pemilik & Pemilik & Varchar & 30 & \\
\hline
\end{tabular}

Tabel 5. Tabel Buku Tamu

\begin{tabular}{|c|c|c|c|c|c|}
\hline No & Elemen Data & Akronim & Tipe & Panjang & Keterangan \\
\hline 1 & Idbukutm & Idadmin & Int & 10 & Primary Key, Auto Increment \\
\hline 2 & Email & Namaadmin & Varchar & 50 & \\
\hline 3 & Nama & Login & Varchar & 40 & \\
\hline 4 & Komentar & Passwd & Text & & \\
\hline 5 & Respon & Respon & Text & & \\
\hline 6 & Tgl Pos & Tglpost & Timestamp & & \\
\hline 7 & Tampilkan & Tampilkan & int & 1 & \\
\hline
\end{tabular}

\section{Struktur Navigasi}

a. Pengunjung

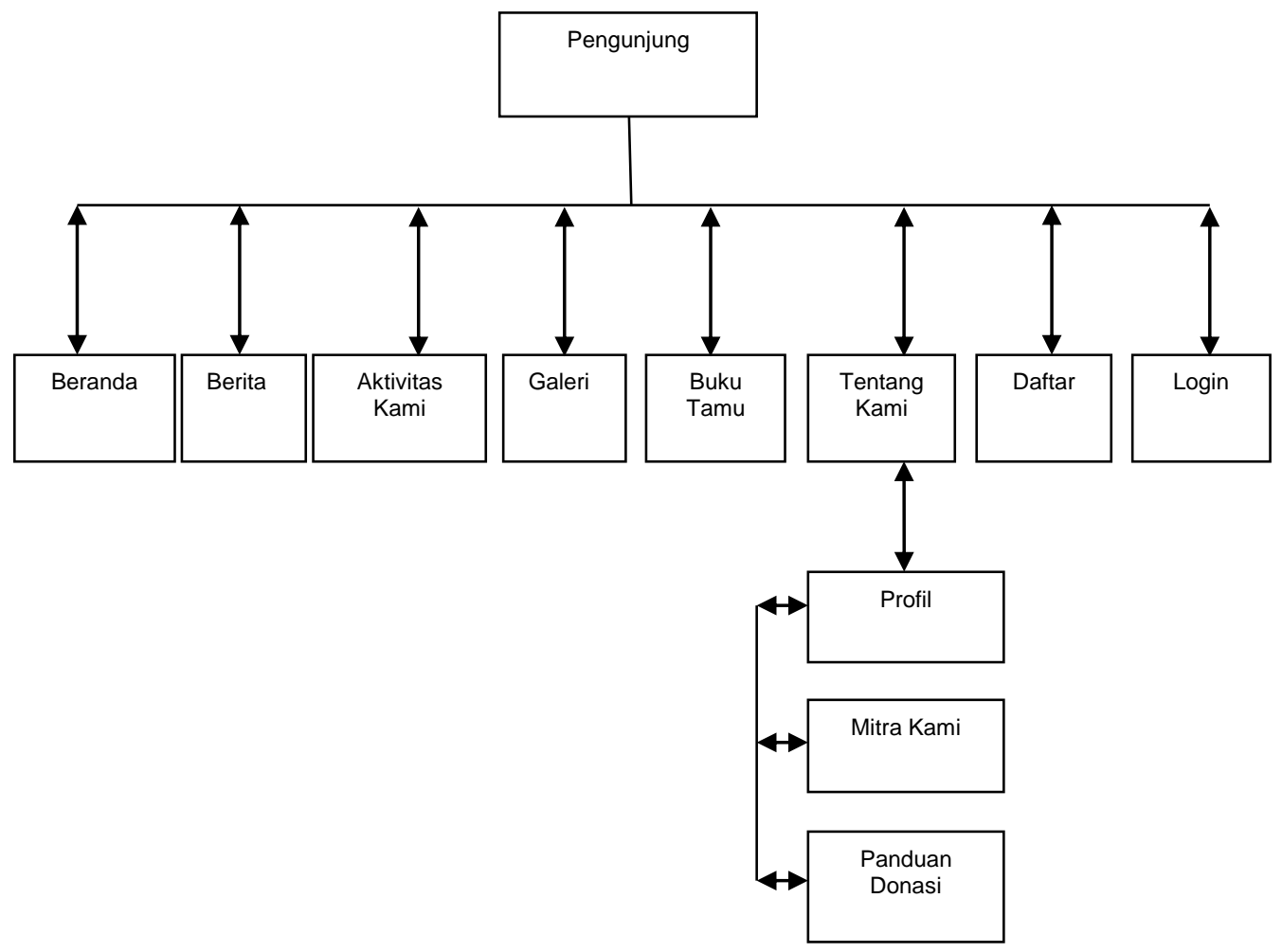

Gambar 3. Struktur Navigasi Pengunjung 
b. Donatur

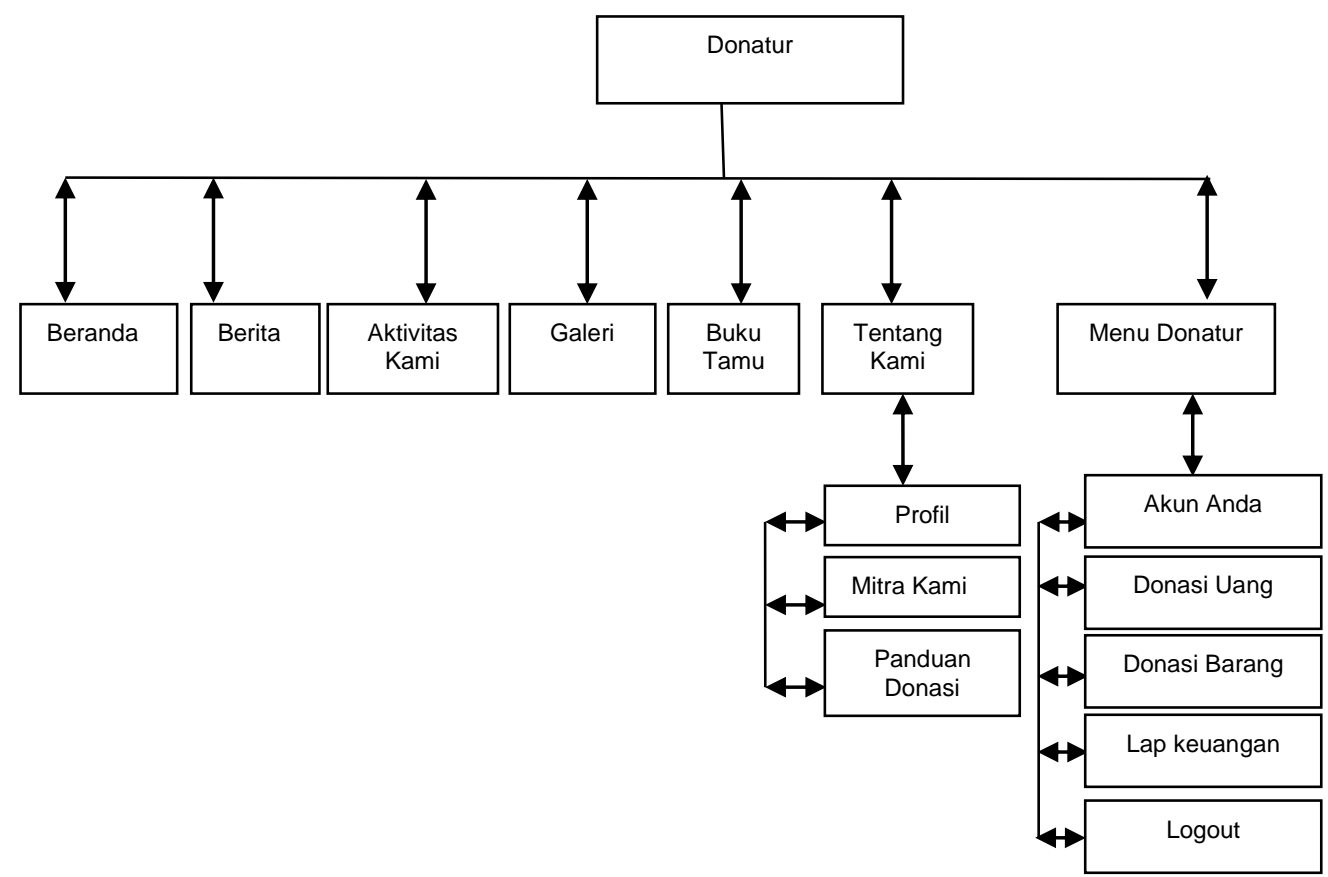

Gambar 4. Struktur Navigasi Donatur

c. Admin

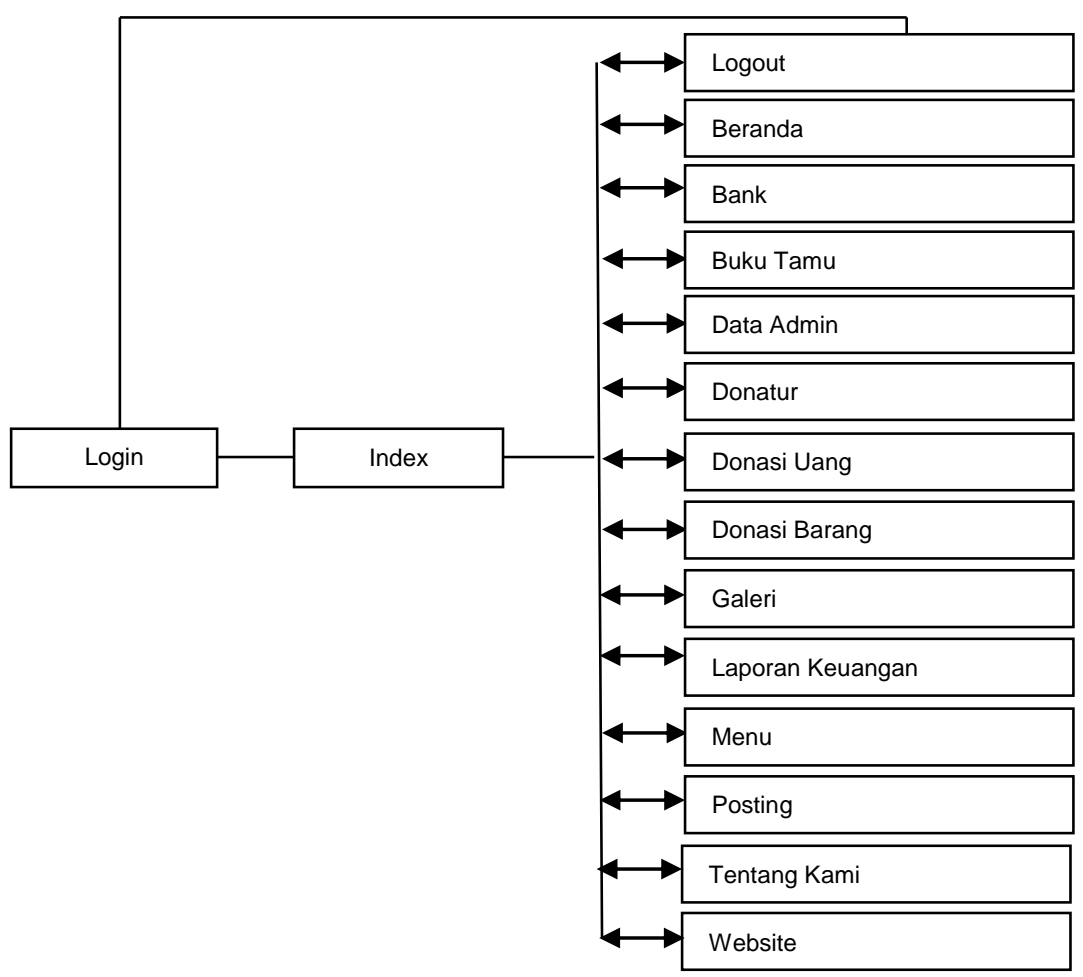

Gambar 5. Struktur Navigasi Admin 
6. Implementasi

a. Halaman Pengunjung

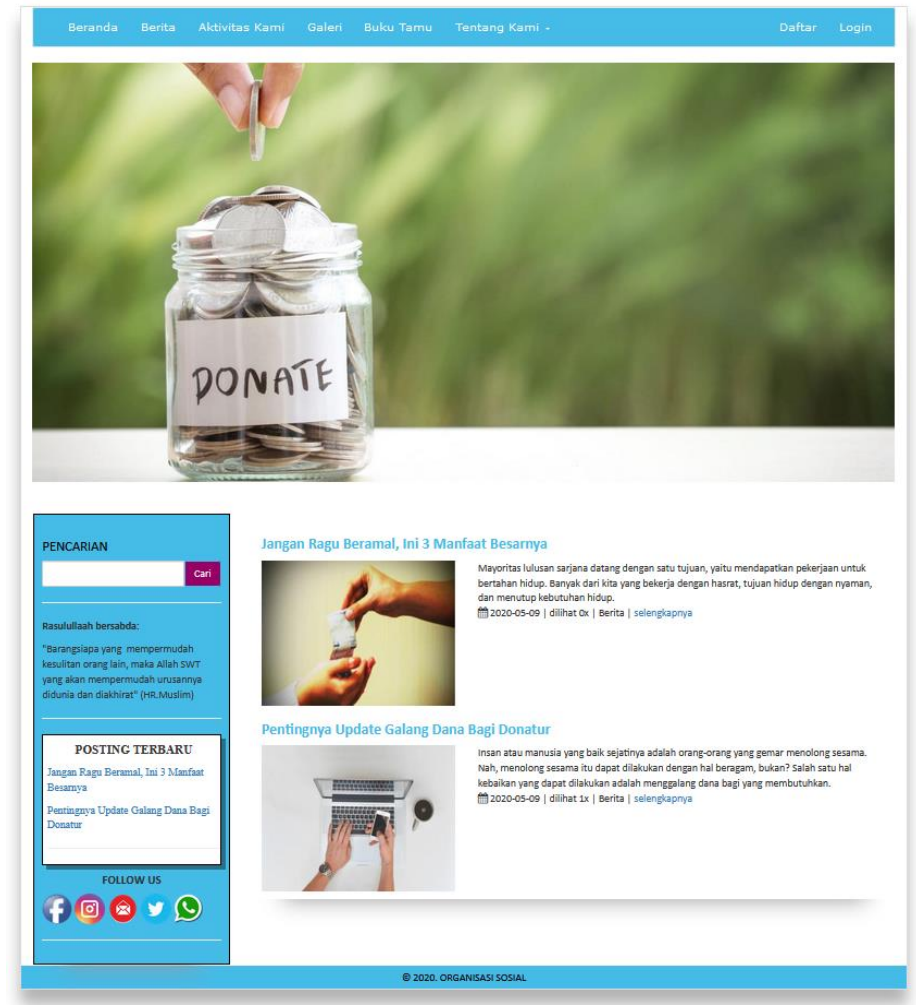

Gambar 6. Implementasi Halaman Pengunjung

b. Halaman Login Donatur

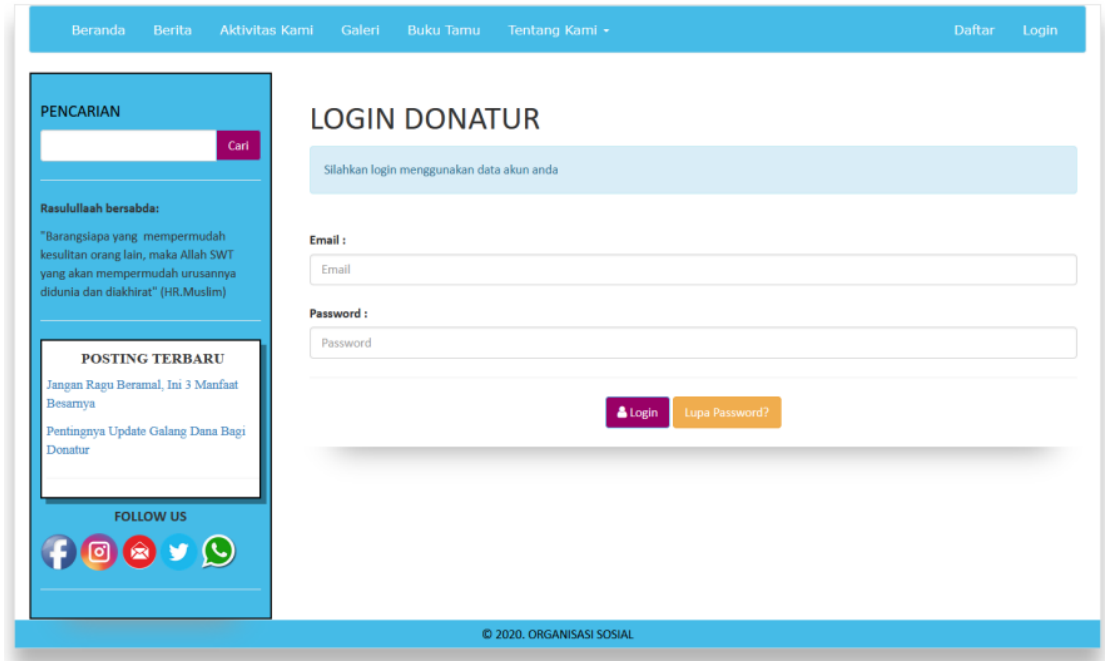

Gambar 7. Implementasi Halaman Login Donatur 
c. Halaman Donasi Uang

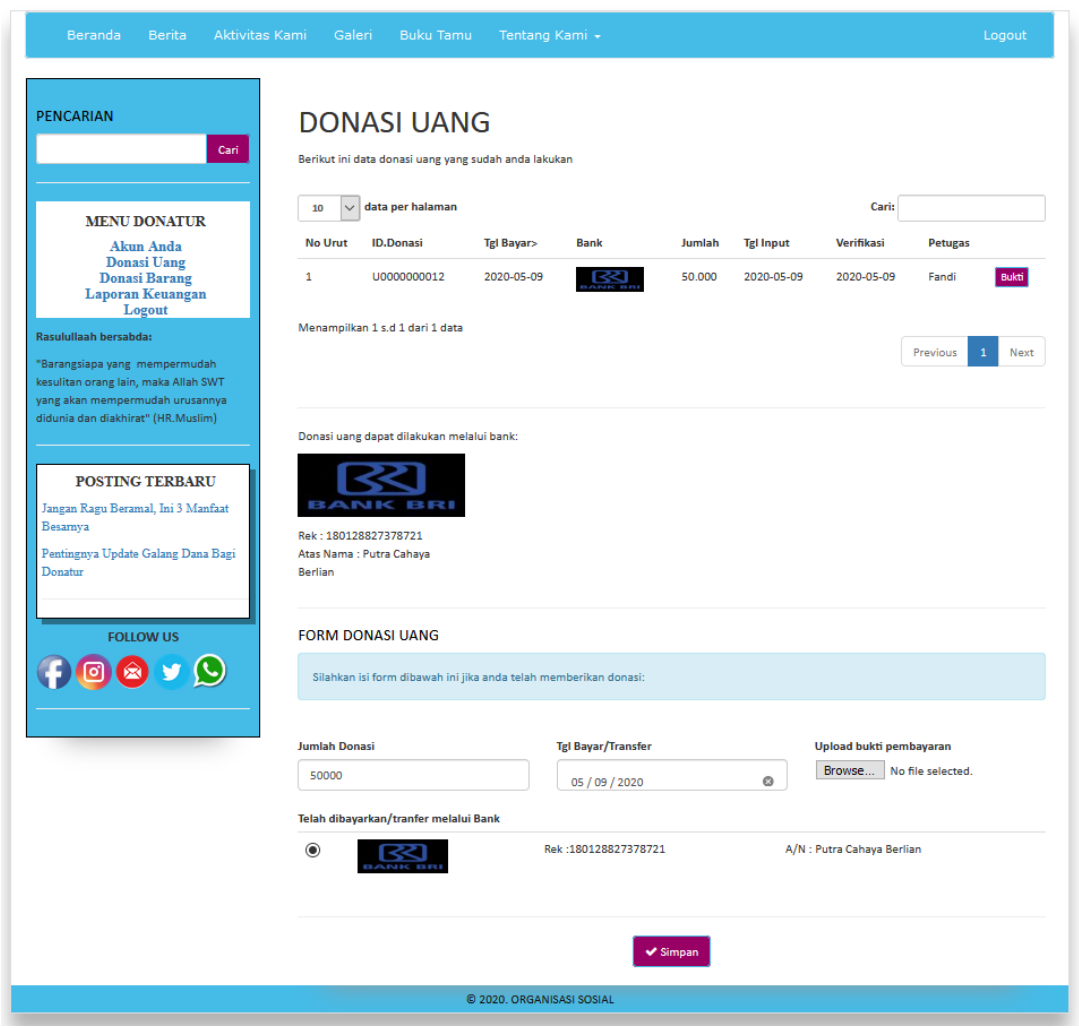

Gambar 8. Implementasi Halaman Donasi Uang

d. Halaman Donasi Barang

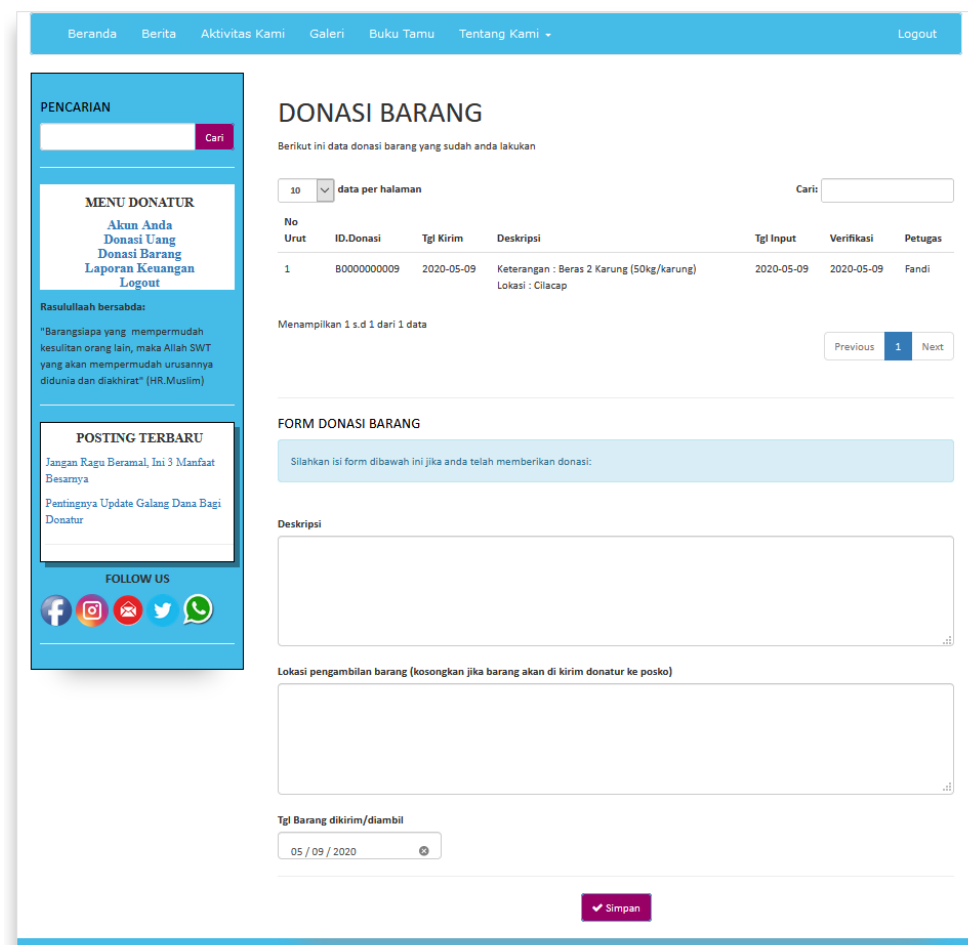

Gambar 9. Implementasi Halaman Donasi Barang 
e. Halaman Laporan Keuangan

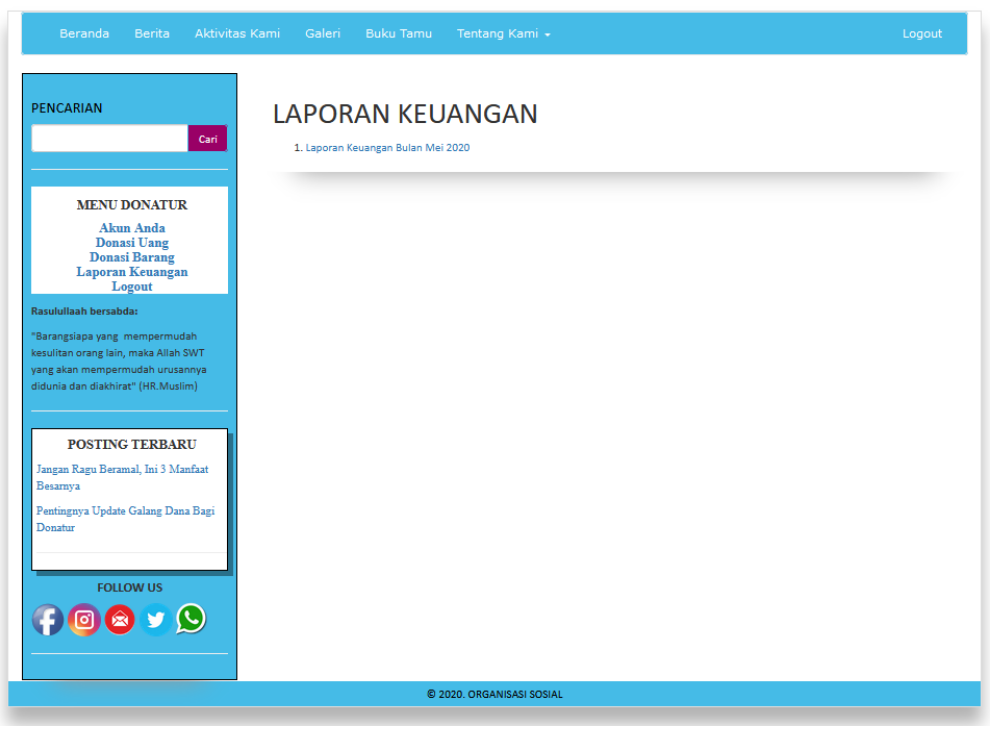

Gambar 10. Implementasi Halaman Laporan Keuangan

\section{Blackbox Testing}

Pada tahap ini, pengujian dimaksudkan untuk mengetahui apakah fungsi-fungsi, masukan dan keluaran dari perangkat lunak sesuai dengan spesifikasi yang dibutuhkan.

a. Pengujian Halaman Login Admin

Tabel 5. Hasil pengujian Login Admin

\begin{tabular}{|c|c|c|c|c|c|}
\hline No & Skenario Pengujian & Text case & Hasil yang diharapkan & $\begin{array}{c}\text { Hasil } \\
\text { Pengujian }\end{array}$ & Kesimpulan \\
\hline 1. & $\begin{array}{l}\text { Nama tidak diisi, } \\
\text { Password tidak diisi, } \\
\text { kemudian klik login. }\end{array}$ & $\begin{array}{l}\text { Nama: } \\
\text { (kosong) } \\
\text { Password: } \\
\text { (kosong) }\end{array}$ & $\begin{array}{l}\text { Sistem akan menolak dan } \\
\text { menampilkan pesan } \\
\text { "please fill out this field". }\end{array}$ & $\begin{array}{c}\text { Sesuai } \\
\text { Harapan }\end{array}$ & Valid \\
\hline 2. & $\begin{array}{l}\text { Nama diisi salah, } \\
\text { Password diisi benar, } \\
\text { kemudian klik login }\end{array}$ & $\begin{array}{l}\text { Nama: } \\
\text { (iman) } \\
\text { password: } \\
(12345)\end{array}$ & $\begin{array}{l}\text { Sistem akan menolak dan } \\
\text { menampilkan pesan } \\
\text { "username atau password } \\
\text { salah". }\end{array}$ & $\begin{array}{c}\text { Sesuai } \\
\text { Harapan }\end{array}$ & Valid \\
\hline 3. & $\begin{array}{l}\text { Nama diisi benar, } \\
\text { Password diisi salah, } \\
\text { kemudian klik login }\end{array}$ & $\begin{array}{l}\text { Nama: } \\
\text { (fandi) } \\
\text { Password: } \\
\text { (54321) }\end{array}$ & $\begin{array}{l}\text { Sistem akan menolak dan } \\
\text { menampilkan pesan } \\
\text { "username atau password } \\
\text { salah". }\end{array}$ & $\begin{array}{l}\text { Sesuai } \\
\text { Harapan }\end{array}$ & Valid \\
\hline 4. & $\begin{array}{l}\text { Nama diisi benar, } \\
\text { Password diisi benar, } \\
\text { kemudian klik login. }\end{array}$ & $\begin{array}{l}\text { Nama: } \\
\text { (fandi) } \\
\text { Password: } \\
\text { (12345) }\end{array}$ & $\begin{array}{l}\text { Sistem akan menerima } \\
\text { dan } \\
\text { halaman admin. }\end{array}$ & $\begin{array}{c}\text { Sesuai } \\
\text { harapan }\end{array}$ & valid \\
\hline
\end{tabular}

b. Pengujian Halaman Login Donatur

Tabel 6. Hasil pengujian Login Donatur

\begin{tabular}{|c|c|c|c|c|c|}
\hline No & Skenario Pengujian & Text case & Hasil yang diharapkan & $\begin{array}{c}\text { Hasil } \\
\text { Pengujian }\end{array}$ & Kesimpulan \\
\hline 1. & $\begin{array}{l}\text { Email tidak diisi, } \\
\text { Password tidak diisi, } \\
\text { kemudian klik login. }\end{array}$ & $\begin{array}{l}\text { Email: } \\
\text { (kosong) } \\
\text { Password: } \\
\text { (kosong) }\end{array}$ & $\begin{array}{l}\text { Sistem akan menolak dan } \\
\text { menampilkan } \\
\text { "Harus diisi". }\end{array}$ & $\begin{array}{l}\text { Sesuai } \\
\text { Harapan }\end{array}$ & Valid \\
\hline 2. & $\begin{array}{l}\text { Email diisi salah, } \\
\text { Password diisi benar, } \\
\text { kemudian klik login }\end{array}$ & $\begin{array}{l}\text { Email: } \\
\text { (iman@g } \\
\text { mail.com) } \\
\text { password: } \\
(12345)\end{array}$ & $\begin{array}{l}\text { Sistem akan menolak dan } \\
\text { menampilkan pesan } \\
\text { "gagal login, email atau } \\
\text { password salah". }\end{array}$ & $\begin{array}{l}\text { Sesuai } \\
\text { Harapan }\end{array}$ & Valid \\
\hline
\end{tabular}




\begin{tabular}{|c|l|l|l|c|c|}
\hline 3. & $\begin{array}{l}\text { Email diisi benar, } \\
\text { Password diisi salah, } \\
\text { kemudian klik login }\end{array}$ & $\begin{array}{l}\text { Email: } \\
\text { (fandi@g } \\
\text { mail.com) } \\
\text { Password: } \\
(12345)\end{array}$ & $\begin{array}{l}\text { Sistem akan menolak dan } \\
\text { menampilkan pesan } \\
\text { "gagal login, email atau } \\
\text { password salah". }\end{array}$ & $\begin{array}{c}\text { Sesuai } \\
\text { Harapan }\end{array}$ & Valid \\
\hline 4. & $\begin{array}{l}\text { Email diisi benar, } \\
\text { Password diisi benar, } \\
\text { kemudian klik login. }\end{array}$ & $\begin{array}{l}\text { Email: } \\
\text { (fandi@g } \\
\text { mail.com) } \\
\text { Password: } \\
(12345)\end{array}$ & $\begin{array}{l}\text { Sistem akan menerima } \\
\text { dan menampilkan } \\
\text { halaman admin. }\end{array}$ & $\begin{array}{c}\text { Sesuai harapan } \\
\text { halid }\end{array}$ & valid \\
\hline
\end{tabular}

c. Pengujian Buku Tamu

Tabel 7. Hasil pengujian Buku Tamu

\begin{tabular}{|c|c|c|c|c|c|}
\hline No & Skenario Pengujian & Text case & Hasil yang diharapkan & $\begin{array}{c}\text { Hasil } \\
\text { Pengujian }\end{array}$ & Kesimpulan \\
\hline 1. & $\begin{array}{l}\text { Nama tidak diisi, Email } \\
\text { tidak diisi, Komentar } \\
\text { tidak diisi, kemudian } \\
\text { klik Kirim. }\end{array}$ & $\begin{array}{l}\text { Nama: } \\
\text { (kosong) } \\
\text { Email: } \\
\text { (kosong) } \\
\text { Komentar: } \\
\text { (kosong) }\end{array}$ & $\begin{array}{l}\text { Sistem akan menolak dan } \\
\text { menampilkan pesan } \\
\text { "please fill out this field". }\end{array}$ & $\begin{array}{c}\text { Sesuai } \\
\text { Harapan }\end{array}$ & Valid \\
\hline 2. & $\begin{array}{l}\text { Nama diisi, Email diisi, } \\
\text { Komentar diisi, } \\
\text { kemudian klik Kirim. }\end{array}$ & $\begin{array}{l}\text { Nama: } \\
\text { (Fandi) } \\
\text { Email: } \\
\text { (fandi@g } \\
\text { mail.com) } \\
\text { Komentar: } \\
\text { (berkunjun } \\
\text { g) }\end{array}$ & $\begin{array}{lr}\text { Sistem akan } & \text { dan } \\
\text { menampilkan } & \text { pesan } \\
\text { "Komentar anda sudah } \\
\text { tersimpan, kami akan } \\
\text { segera menindaklanjuti. } \\
\text { Terima kasih :)". }\end{array}$ & $\begin{array}{c}\text { Sesuai } \\
\text { Harapan }\end{array}$ & Valid \\
\hline
\end{tabular}

\section{E. KESIMPULAN}

1. Dengan adanya sistem ini, para donatur dapat menyalurkan donasi secara online tanpa harus datang secara langsung ke lembaga atau organisasi sosial.

2. Penggunaan website akan memudahkan pihak lembaga ataupun organisasi sosial dalam mengelola data donatur dan transaksi donasi serta pembuatan laporan.

\section{REFERENSI}

Ahmad, C., \& Hermawan, D. (2014). E-Business \& E-Commerce. Yogyakarta: Penerbit Andi.

Andriansyah, D. (2016). Sistem Informasi Pendaftaran Event Dengan PHP Untuk Panduan Skripsi. Cirebon: CV. ASFA Solution.

Firman, A., Wowor, H. F., Najoan, X., Teknik, J., Fakultas, E., \&amp; Unsrat, T. (2016). Sistem Informasi Perpustakaan Online Berbasis Web. E-Journal Teknik Elektro Dan Komputer, $5(2), 29-36$

Imaniawan, fabriyan fandi dwi, \& Elsa, umi maelani. (2017). Sistem Informasi Penjualan Sepatu Berbasis Web Pada Vegas Hyper Purwokerto. IJSE - Indonesian Journal on Software Engineering, 3(2), 82-91. https://ejournal.bsi.ac.id/ejurnal/index.php/ijse/article/view/3000/1937 (Diakses 1 April 2020)

Mulyanto, J. D., \& Khasanah, U. (2018). Aplikasi Pembayaran DSP dan SPP Sekolah Pada SMK TI Bintra Purwokerto. Evolusi - Jurnal Sains Dan Manajemen AMIK BSI Purwokerto, 6(1), 49-60. https://ejournal.bsi.ac.id/ejurnal/index.php/evolusi/article/view/3544 (Diakses 1 April 2020)

Nurromlah, Yuri Rahayu, L. S. R. (2017). Perancangan Sistem Informasi Penerimaan Dan Penyaluran Donasi Pada Dpu-Dt. Indonesian Journal on Computer and Information Technology, 2(1), 2. https://ejournal.unsrat.ac.id/index.php/emba/article/view/4518/4047 (Diakses 1 April 2020)

Prasetyo, E. (2015). Rancang Bangun SistemInformasi Sekolah Tinggi Ilmu Ekonomi Rahmanyah Kabupaten Musi Banyuasin Berbasis Website. Jurnal Informatika, 1(2), 19- 
30. https://s3.amazonaws.com/academia.edu.documents/38664524/Jurnal_Ekkal_Polsky_.p df?AWSAccessKeyld=AKIAIWOWYYGZ2Y53UL3A\&Expires $=1524079547 \&$ Signature $=\mathrm{jH}$ D0VW7Udfw0NFF8q4NCDu90e18\%3D\&response-content-disposition=inline\%3B filename\%3DRancang_Bangun_Sistem_Info

Tabrani, M. (2014). Implementasi Sistem Informasi Reservasi Penginapan Pada Argowisata Gunung Mas Cisarua Bogor. Bianglala Informatika, II(1), 33-42. http://ejournal.bsi.ac.id/ejurnal/index.php/Bianglala/article/view/559 (Diakses 1 April 2020)

Supriyanta, \& Nussy, E. (2016). Perancangan Website Sebagai Media Informasi Panti Asuhan Batu Penjuru Kulon Progo. Speed - Sentra Penelitian Engineering dan Edukasi, 8(2), 1722. http://speed.web.id/ejournal/index.php/speed/article/view/26 (Diakses 1 April 2020). Yanto, R. (2016). Manajemen Basis Data Menggunakan MYSQL. Yogyakarta: Deepublish. 